\title{
Egyptian Propolis Alleviates Gentamicin-Induced Nephrotoxicity in Rats
}

\author{
Attia H. Atta ${ }^{1}$, Soad M. Nasr ${ }^{2}$, Samar M. Mouneir, ${ }^{1,}$, Sekena H. Abdel-Aziem ${ }^{4}$ and Somia A.
} Nassar $^{2,5}$

${ }^{1}$ Department of Pharmacology, Faculty of Veterinary Medicine, Cairo University, Giza 12211, Egypt.

E-mail address: attaattia52@yahoo.com

${ }^{2}$ Department of Parasitology and Animal Diseases, National Research center, El-Behoth Street, Dokki, Post

Box, 12622, Giza, Egypt.

E-mail address: soadnasr@yahoo.com

${ }^{3 *}$ corresponding author: Department of Pharmacology, Faculty of Clinical Pharmacy, Taif University, KSA

E-mail address:Samar_mouneir@yahoo.com

${ }^{4}$ Department of Cell Biology, National Research Centre, El-Behoth Street, Dokki, Giza. Egypt.

E-mail address: nadanahl@yahoo.com

5- E-mail address: somianassar@ymail.com

\begin{abstract}
The objective of this study was to evaluate the effectiveness of oral administration of ethanol extract of propolis against gentamicin induced nephrotoxicity in rats. Oral administration of ethanol extract of propolis (EEP) at doses 25, 50 and 100 $\mathrm{mg} / \mathrm{kg}$. b.wt. orally/daily for 7 days) against gentamicin (GM) at dose $100 \mathrm{mg} / \mathrm{kg}$ b.wt., i.p./daily for 7days) induced nephrotoxicity in six equal groups of adult male Sprague-Dawley rats. Blood was collected $24 \mathrm{~h}$ after the last injection for determination of serum creatinine, urea, and aspartate aminotransferase (AST) activity. Rats were euthanized and kidney tissue specimens were collected for determination of oxidative/antioxidative biomarkers, gene expression for antioxidative enzymes and DNA fragmentation. Results revealed that there was a significant increase in creatinine and urea levels and AST activity in serum of rats treated with GM only compared to control group. Lipid peroxidation in renal tissue showed significant elevation in GM-only treated group, however, superoxide dismutase, glutathione peroxidase and catalase and its gene expression were markedly decreased. DNA fragmentation was significantly increased in renal tissue of GM only treated rats. Oral administration of EEP exhibited curative effects by reversing GM-induced alterations in serum biochemical and renal tissue oxidative stress biomarkers. In conclusion, propolis is effective in preventing or ameliorating oxidative stress of gentamicin.
\end{abstract}

Key words: Propolis; Gentamicin; Nephroprotective; Antioxidants enzymes; gene expression; DNA fragmentation; Rats.

\section{Council for Innovative Research}

Peer Review Research Publishing System

\section{Journal: Journal of Advances in Chemistry}

Vol. 6, No. 3

editor@cirworld.com

www.cirworld.com, member.cirworld.com 


\section{INTRODUCTION}

Gentamicin (GM) is an aminoglycoside antibiotic which is used in clinical practice to treat severe gram-negative infections [1]. The incidence of aminoglycosides-induced nephrotoxicity has increased and about $30 \%$ of patients treated with GM for more than 7 days show some signs of nephrotoxicity [2]. Other investigators have suggested that aminoglycosides antibiotics can stimulate formation of free radicals [3]. There have been many studies suggesting a significant role for reactive oxygen species (ROS) in GM-induced nephrotoxicity [4]. ROS scavengers and antioxidants have been used to ameliorate the GM-induced nephrotoxicity [5].

Oxidative stress is a disturbance in the balance between production of ROS and antioxidant defense. Free radicals are continuously produced during normal physiologic events and attack macromolecules including proteins, DNA, and lipids, causing tissue injury. The body has developed major antioxidant defense mechanisms for the removal of free radicals.

Propolis is a resinous hive product, produced by honey bees from various plant sources. The chemical composition of raw Egyptian propolis sample (collected from Dakahlia Governorate) as investigated by GC/MS, 65 compounds were identified, such as aromatic acids: benzoic, cinnamic, trans-p-coumaric, 3,4- dimethoxycinnamic, ferulic and caffeic acids. Of the 19 esters identified, Egyptian propolis contained 11 caffeate esters including two new to propolis, tetradecenyl caffeate (isomer) and tetradecanyl caffeate. Egyptian propolis contained some new triterpenoids including lupeol and alpha-amyrin. It also contained flavonoids, sugar, and aliphatic acids. The investigators stated that Dakahlia propolis sample was a typical popular propolis [6].

Propolis possesses a broad spectrum of biological activities, enhances immune system activities [7, 8] and oxygen radical scavenging [9]. Biological and therapeutic actions of propolis are generally attributed to its constituents of plant origin, mainly phenolics. Flavonoids are well-known to possess antioxidant activity, mainly via their free radical scavenging activity and metal chelating properties [10]. Strong antioxidant properties for different propolis samples using different chemical assays, such as scavenging of DPPH (2,2-diphenyl-1-picrylhydrazyl) radical [11], scavenging of superoxide anion and inhibition of DNA cleavage induced by hydrogen peroxide UV-photolysis [12]. Recently it has been shown that propolis decreased lipid peroxidation and augmented the activity of antioxidant enzymes in the kidneys of diabetic rats [13].

In the present study, we aimed evaluate the effectiveness of oral administration of ethanol extract of propolis against gentamicin induced nephrotoxicity in rats. The activity of antioxidant enzymes associated with GM nephrotoxicity and the effect of propolis on gene expression of superoxide dismutase (SOD), glutathione peroxidase (GPx), and catalase (CAT) as well as DNA fragmentation in kidney tissue was studied.

\section{MATERIAL and METHODS}

This study was carried out according to guidelines for animal experimentation, and approved by the Institutional Animal Care and Use Committee, National Research Centre Animal Care Unit, Dokki, Giza, Egypt.

Gentamicin sulfate (Memphis Co. for Pharmaceutical \& Chemical Industries, Cairo, Egypt) for injection was used. All chemicals used were of good quality and analytical grade.

\subsection{Propolis Extraction}

Fifty grams of the resinous material of Egyptian propolis (obtained from Dakahlia Governorate, Egypt) were cut into small pieces and extracted at room temperature with $100 \mathrm{ml}$ of $80 \%$ ethanol for $24 \mathrm{~h}$. The extraction was performed twice. The alcoholic extract was evaporated under vacuum at $50^{\circ} \mathrm{C}$ until dryness. Dried ethanol extract of propolis (EEP) (yield $14 \mathrm{~g}$ ) was suspended in phosphate buffered saline, $\mathrm{pH} 7.2$ [6]. A voucher sample of the used Egyptian propolis was kept at the Pharmacology Department, Faculty of Veterinary Medicine, Cairo University, Egypt.

\subsection{Animals}

Thirty-six adult male Sprague-Dawley rats of $140-150 \mathrm{~g}$ body weight were used in this study. Animals were housed in a well-ventilated animal room under standardized conditions of $24^{\circ} \mathrm{C}$; relative humidity $50 \pm 5 \%$ and $12 \mathrm{~h}$ light/dark cycle at the Animal House, National Research Center, Giza, Egypt. Feed and water were supplied ad libitum to meet the requirements of the NRC [14]. Rats were acclimatized for 15 days before the start of the experiment.

\subsection{General Layout of the Experiment}

Rats were randomly divided into six equal groups. The first group was injected i.p. with sterile normal saline $(0.2 \mathrm{ml} / \mathrm{day})$. The second group was injected i.p. with gentamicin at dose $100 \mathrm{mg} / \mathrm{kg}$ b.wt. The third group was administrated EEP orally at dose $100 \mathrm{mg} / \mathrm{kg}$ b.wt. Rats in the 4th to the 6th group were injected with gentamicin i.p. at the same dose simultaneously with EEP orally at doses 25,50 and $100 \mathrm{mg} / \mathrm{kg}$ b.wt., respectively. All treatments extended for 7 days. Twenty four $\mathrm{h}$ after the last injection, blood was collected by retro orbital venous plexus puncture and was used for separation of serum to assess urea and creatinine levels and aspartate aminotransferase activity. Rats were then euthanized and kidney tissue specimens were collected and stored at $-80^{\circ} \mathrm{C}$ until analyzed for evaluation of the oxidant/antioxidant parameters, gene expression of the GPx, SOD and CAT and DNA fragmentation. 


\subsection{Renal Functions Assessment}

Enzymatic determination of serum urea [15], creatinine levels [16] and aspartate aminotransferase (AST) activity [17] were determined using test kits (bioMérieux, France). Measurements were performed using Spectrophotometer model T80, UV/Visible, double beam, UK.

\subsection{Oxidant/antioxidant Biomarkers Assessment}

\subsubsection{Preparation of Kidney Homogenate}

At the end of the experiment, $0.5 \mathrm{~g}$ of kidney tissue was collected from each rat, washed in ice-cold $0.9 \% \mathrm{NaCl}$ and homogenized in ice-cold $1.15 \%$ solution of potassium chloride in $50 \mathrm{mM}$ potassium phosphate buffer solution (pH 7.4) to yield a 10\% (W/V) homogenate. Homogenization was performed using Sonicator (4710 Ultrasonics Homogenizer, USA). The homogenate was centrifuged at $4,000 \times \mathrm{g}$ for $5 \mathrm{~min}$ at $4^{\circ} \mathrm{C}$. The supernatant was collected and used for determination of the concentration of reduced glutathione (GSH) and lipid peroxidation byproducts (LPx, expressed as malondialdehyde) and the activity of GPx, SOD and CAT as well as total protein concentration was used to express the enzymatic activity as /mg protein.

\subsubsection{Assessment of Oxidant/antioxidant Biomarkers and Total Protein Concentration}

GSH content of kidney homogenate was determined using Ellman's reagent [18] and its concentration was expressed as $\mathrm{mM} / \mathrm{mg}$ protein. LPx were determined in renal tissue homogenate [18]. Level of Lipid peroxides was expressed as $\mathrm{nM} / \mathrm{g}$ tissue. Renal GPx activity was measured [20] and the assay was an indirect measurement of the activity of GPx. The activity of GPx was expressed as U/mg protein. The renal SOD activity [21] and CAT [22] activities were measured in renal homogenate and their activity was expressed as $\mathrm{U} / \mathrm{mg}$ protein. Renal total protein concentration was measured using bovine serum as a standard [23]. All parameters were analyzed spectrophotometerically (Spectrophotometer; T80 UV/VIS PG instrument Ltd, UK) using Test kits from Bio-diagnostic, Dokki, Egypt.

\subsection{Gene Expression}

\subsubsection{RNA Extraction and Semi-Quantitative RT-PCR}

Kidney samples $(200 \mathrm{mg}$ ) were quickly thawed and homogenized in $2 \mathrm{ml}$ of Trizol and total RNA was isolated according to the manufacturer's directions. RNA was resuspended in RNase-free water, quantitated using UV spectrophotometer, and stored at $-80^{\circ} \mathrm{C}$. The quality of the isolated RNA was assessed by measuring the absorbance at $260 \mathrm{~nm}$, analyzing the A260/A280 ratio (1.7- 2).

For cDNA synthesis, $3 \mu \mathrm{g}$ of total RNA were heated to $70^{\circ} \mathrm{C}$ for $10 \mathrm{~min}$ then placed immediately on ice for $10 \mathrm{~min}$. To each sample, $4 \mu \mathrm{l}$ of $5 \mathrm{x}$ first strand buffer, $2 \mu \mathrm{l}$ of $0.1 \mathrm{~mol} / \mathrm{I} \mathrm{DTT}, 4 \mathrm{AL}$ of $2 \mathrm{mmol} / \mathrm{l}$ each deoxynucleotide triphosphate mix, $1 \mu \mathrm{L}$ of oligo (dT) primer and $1 \mu \mathrm{l}$ of Superscript II reverse transcriptase were added. Reverse transcription was then carried out at $42^{\circ} \mathrm{C}$ for $50 \mathrm{~min}$, followed by heating to $70^{\circ} \mathrm{C}$ for $15 \mathrm{~min}$ and cDNA samples were stored at $-20^{\circ} \mathrm{C}$ until assayed. cDNAs were amplified using specific primers for rats GPx, SOD and CAT (Table 1). Gene expression was assayed according to the manufacturer's instruction. The PCR program cycles were set as follows: initial denaturing at $95^{\circ} \mathrm{C}$ for $20 \mathrm{~s}$, followed by 40 cycles $\left(95^{\circ} \mathrm{C}\right.$ for $3 \mathrm{~s}, 60^{\circ} \mathrm{C}$ for $\left.30 \mathrm{~s}\right) . \beta$-actin mRNA was used as an internal standard, GPx, SOD and CAT mRNA expressions were determined by quantitative reverse transcription-PCR (RT-PCR) and normalized against $\beta$-actin mRNA levels. The PCR product was run on a $2 \%$ agarose gel in Tris-borate-EDTA buffer and visualized over a UV Trans-illuminator. The ethidium bromide-stained gel bands were scanned and the signal intensities were quantified by the computerized Gel-Pro (version 3.1 for window 3). The ratio between the levels of the target gene amplification product and the $\beta$-actin (internal control) was calculated to normalize for initial variation in sample concentration as a control for reaction efficiency [24].

Table (1): Summary of the primers performed in PCR amplification.

\begin{tabular}{|c|c|c|c|c|}
\hline Primers & Sequences & $\begin{array}{c}\text { Annealing } \\
\text { Temperature } \\
\left({ }^{\circ} \mathrm{C}\right)\end{array}$ & References & Size \\
\hline \multirow[t]{2}{*}{$\beta$-Actin } & 5-CGTGACATTAAGGAGAAGCTGTGC-3 & 64 & \multirow{2}{*}{ [25] } & $374 \mathrm{BP}$ \\
\hline & 5-CTCAGGAGGAGCAATGATCTTGAT-3 & & & \\
\hline \multirow[t]{2}{*}{ SOD1 } & 5-GTGCTGAAGGGCGACG-3 & 58 & \multirow{2}{*}{ [26] } & $370 \mathrm{BP}$ \\
\hline & 5-TTTCCACCTTTGCCCAAG-3 & & & \\
\hline \multirow[t]{2}{*}{ GPx } & 5-GGGCTCCCTGCGGGGCAAGGT-3 & 64 & \multirow{2}{*}{ [27] } & $354 \mathrm{BP}$ \\
\hline & 5-ATGTACTTGGGGTCGGTCATG-3 & & & \\
\hline \multirow[t]{2}{*}{ CAT } & 5-GCAGATACCTGTGAACTGTC-3 & 59 & \multirow{2}{*}{ [28] } & $229 \mathrm{BP}$ \\
\hline & 5-GTAGAATGTCCGCACCTGAG-3 & & & \\
\hline
\end{tabular}




\subsubsection{DNA Fragmentation Assay}

\subsubsection{DNA Extraction}

DNA fragmentation was used as a measure of apoptotic. The presence of DNA ladder was determined according to the modified method $[29,30]$. The absorbance of the DNA solution was read spectrophotometrically at absorbance of 260 and $280 \mathrm{~nm}$. Equal amounts of DNA were taken after spectrophotometric analysis [31].

\subsubsection{Agarose Gel Electrophoresis}

A gel was prepared with $2 \%$ agarose containing $0.1 \%$ ethidium bromide. The gel was electrophoresed using the submarine gel electrophoresis machine. The DNA was visualized and photographed with illumination under UV light.

\subsection{Statistical Analysis}

Data were presented as mean \pm standard error. Differences between control and treated groups were tested for significance using one-way analysis of variance (ANOVA) followed by Duncan's multiple range test. Differences were considered significant at $P<0.05$ level using SPSS version 15 computer program [32].

\section{RESULTS}

\subsection{Effect of propolis on serum creatinine, urea levels and the activity of AST}

GM significantly $(P<0.05)$ elevated serum creatinine and urea levels and increased the activity of serum AST when compared to control group. Simultaneous administration of EEP orally at doses 25,50 and $100 \mathrm{~g} / \mathrm{kg}$ b.wt., respectively with GM maintained serum creatinine, urea levels and AST activity at levels comparable to those of normal control and significantly $(P<0.05)$ lower than those of GM-alone treated groups (Table 2$)$.

Table (2) Effect of propolis on serum creatinine, urea and serum and renal tissue AST in rats treated with gentamicin (100mg/kg,i.p.)

\begin{tabular}{|l|c|c|c|}
\hline \multicolumn{1}{|c|}{ Parameters } & \multicolumn{1}{|c|}{$\begin{array}{c}\text { Creatinine } \\
\text { (mg/d) }\end{array}$} & $\begin{array}{c}\text { Urea } \\
\text { (mg/dl) }\end{array}$ & $\begin{array}{c}\text { Aspartate } \\
\text { aminotransferase } \\
\text { (AST) (IU/L) }\end{array}$ \\
\hline $\begin{array}{l}\text { Control } \\
\text { (normal saline) }\end{array}$ & $0.54 \pm 0.04^{\mathrm{c}}$ & $30.95 \pm 2.44^{\mathrm{d}}$ & $146.87 \pm 1.97^{\mathrm{b}}$ \\
\hline $\begin{array}{l}\text { Gentamicin } \\
\text { (100mg.kg/b.wt.i.p.) }\end{array}$ & $2.05 \pm 0.05^{\mathrm{a}}$ & $68.46 \pm 2.54^{\mathrm{a}}$ & $191.53 \pm 3.15^{\mathrm{a}}$ \\
\hline Propolis(100mg.kg/b.wt.orally) & $0.63 \pm 0.03^{\mathrm{c}}$ & $34.17 \pm 1.94^{\mathrm{cd}}$ & $135.30 \pm 3.51^{\mathrm{bc}}$ \\
\hline $\begin{array}{l}\text { Propolis(25mg.kg/b.wt.orally } \\
\text { +Gentamicin) }\end{array}$ & $0.85 \pm 0.08^{\mathrm{b}}$ & $39.66 \pm 1.57^{\mathrm{bc}}$ & $147.86 \pm 4.34^{\mathrm{b}}$ \\
\hline $\begin{array}{l}\text { Propolis(50mg.kg/b.wt.orally } \\
\text { +Gentamicin) }\end{array}$ & $0.83 \pm 0.05^{\mathrm{b}}$ & $38.36 \pm 1.57^{\mathrm{bc}}$ & $146.58 \pm 3.74^{\mathrm{b}}$ \\
\hline $\begin{array}{l}\text { Propolis(100mg.kg/b.wt.orally } \\
+ \text { +Gentamicin) }\end{array}$ & $0.81 \pm 0.05^{\mathrm{b}}$ & $41.04 \pm 1.63^{\mathrm{b}}$ & $125.85 \pm 8.32^{\mathrm{c}}$ \\
\hline
\end{tabular}

Means with different superscripts in the same column are significantly different at $P<0.05$.

\subsection{Oxidant/antioxidant biomarkers}

GM caused significant $(P<0.05)$ decrease in the level of reduced GSH compared to control group. Propolis (at all doses) elevated GSH levels in renal homogenate of all GM- treated groups. In the opposite manner, GM caused significant $(P$ $<0.05$ ) elevation of LPx, expressed as malondialdehyde, in renal homogenate in comparison with control group. Coadministration of propolis at all doses prevented the GM-induced increase of renal LPx (Table 3).

Oral administration of propolis significantly $(P<0.05)$ increased the activity of GPx, SOD and CAT in renal tissue of GM- treated rats compared to the control group. Propolis at all doses markedly $(P<0.05)$ enhanced the decreased activities of GPx, SOD, and CAT in all GM-treated groups in comparison with GM-alone treated rats (Table 3 ). 
Table 3 Effect of propolis on the activity of antioxidant/oxidant markers in renal tissue homogenate of rats treated with Gentamicin (100mg/kg, i.p.).

\begin{tabular}{|c|c|c|c|c|c|}
\hline Garameter & $\begin{array}{l}\text { Superoxide } \\
\text { dismutase } \\
\text { (SOD) } \\
\text { (U/mg protein) }\end{array}$ & $\begin{array}{c}\text { Catalase } \\
\text { (CAT) } \\
\text { (U/mg protein) }\end{array}$ & $\begin{array}{c}\text { Glutathione } \\
\text { peroxidase } \\
\text { (GPx) } \\
\text { (U/mg protein) }\end{array}$ & $\begin{array}{c}\text { Glutathione } \\
\text { reduced (GSH) } \\
\text { (mM/mg protein) }\end{array}$ & $\begin{array}{l}\text { Lipid peroxidation } \\
\text { byproducts (LPx) } \\
\text { (nM/g tissue) }\end{array}$ \\
\hline $\begin{array}{l}\text { Control } \\
\text { (normal saline) }\end{array}$ & $34.73 \pm 1.27^{b}$ & $3.18 \pm 0.22^{\mathrm{a}}$ & $0.80 \pm 0.02^{b}$ & $33.57 \pm 1.89^{b}$ & $2.02 \pm 0.16^{c}$ \\
\hline $\begin{array}{l}\text { Gentamicin } \\
\text { (100mg.kg/b.wt.i.p.) }\end{array}$ & $22.93 \pm 2.04^{c}$ & $2.06 \pm 0.25^{\mathrm{b}}$ & $0.43 \pm 0.01^{d}$ & $23.00 \pm 0.92^{\mathrm{e}}$ & $6.60 \pm 0.33^{\mathrm{a}}$ \\
\hline $\begin{array}{l}\text { Propolis } \\
\text { (100mg.kg/b.wt. orally) }\end{array}$ & $42.00 \pm 2.82^{a}$ & $3.66 \pm 0.24^{a}$ & $0.87 \pm 0.02^{a}$ & $38.36 \pm 0.61^{a}$ & $1.88 \pm 0.20^{c}$ \\
\hline $\begin{array}{l}\text { Propolis } \\
\text { (25mg.kg/b.wt. orally } \\
\text { +Gentamicin) }\end{array}$ & $33.90 \pm 1.60^{b}$ & $3.18 \pm 0.30^{a}$ & $0.73 \pm 0.02^{c}$ & $31.44 \pm 0.51^{\mathrm{bc}}$ & $2.85 \pm 0.10^{b}$ \\
\hline $\begin{array}{l}\text { Propolis } \\
\text { (50mg.kg/b.wt. orally } \\
\text { +Gentamicin) }\end{array}$ & $34.70 \pm 1.80^{b}$ & $2.94 \pm 0.22^{\mathrm{a}}$ & $0.75 \pm 0.02^{b c}$ & $29.57 \pm 0.79^{c d}$ & $2.94 \pm 0.19^{b}$ \\
\hline $\begin{array}{l}\text { Propolis } \\
\text { (100mg.kg/b.wt. orally } \\
\text { +Gentamicin) }\end{array}$ & $38.90 \pm 1.02^{\mathrm{ab}}$ & $3.33 \pm 0.16^{a}$ & $0.74 \pm 0.02^{c}$ & $27.35 \pm 0.75^{d}$ & $2.43 \pm 0.20^{b c}$ \\
\hline
\end{tabular}

\subsection{Gene Expression}

The ratio of GPx mRNA/ $\beta$-actin (1.5) in GM-alone treated rats indicates a down expression in GPx compared to the ratio between control mRNA/ $\beta$-actin ratio (2.7) (Fig. 1 and 2). Meanwhile, the ratio of SOD mRNA/ $\beta$-actin (0.71) in rats treated with gentamicin was decreased than that of control mRNA / $\beta$-actin (1.07) (Fig. 1 and Fig.3). The ratio of CAT mRNA/ $\beta$ actin (0.55) was decreased in rats treated with gentamicin as compared to control CAT mRNA/ $\beta$-actin (0.70) (Fig. 1 and Fig. 4).

Co-administration of propolis and Gentamicin have increased the ratio of GPx mRNA/ $\beta$-actin compared to Gentamicin alone-treated rats $(2.5,2.6,2.6$ for the GM and three tested doses of propolis, respectively compared to 1.5 for GM alone treated rats). SOD mRNA/ $\beta$-actin ratio has increased after treatment with three tested doses of propolis by 1.16 , 1.03 and 1.02, respectively in comparison with 0.71 for $\mathrm{GM}$ alone treated rats. Moreover, CAT mRNA/ $\beta$-actin ratio was increased after treatment with three tested doses of propolis to reach $0.67,0.69$ and 0.69 respectively vs 0.55 for GMalone treated rats as shown from the results of image analysis 


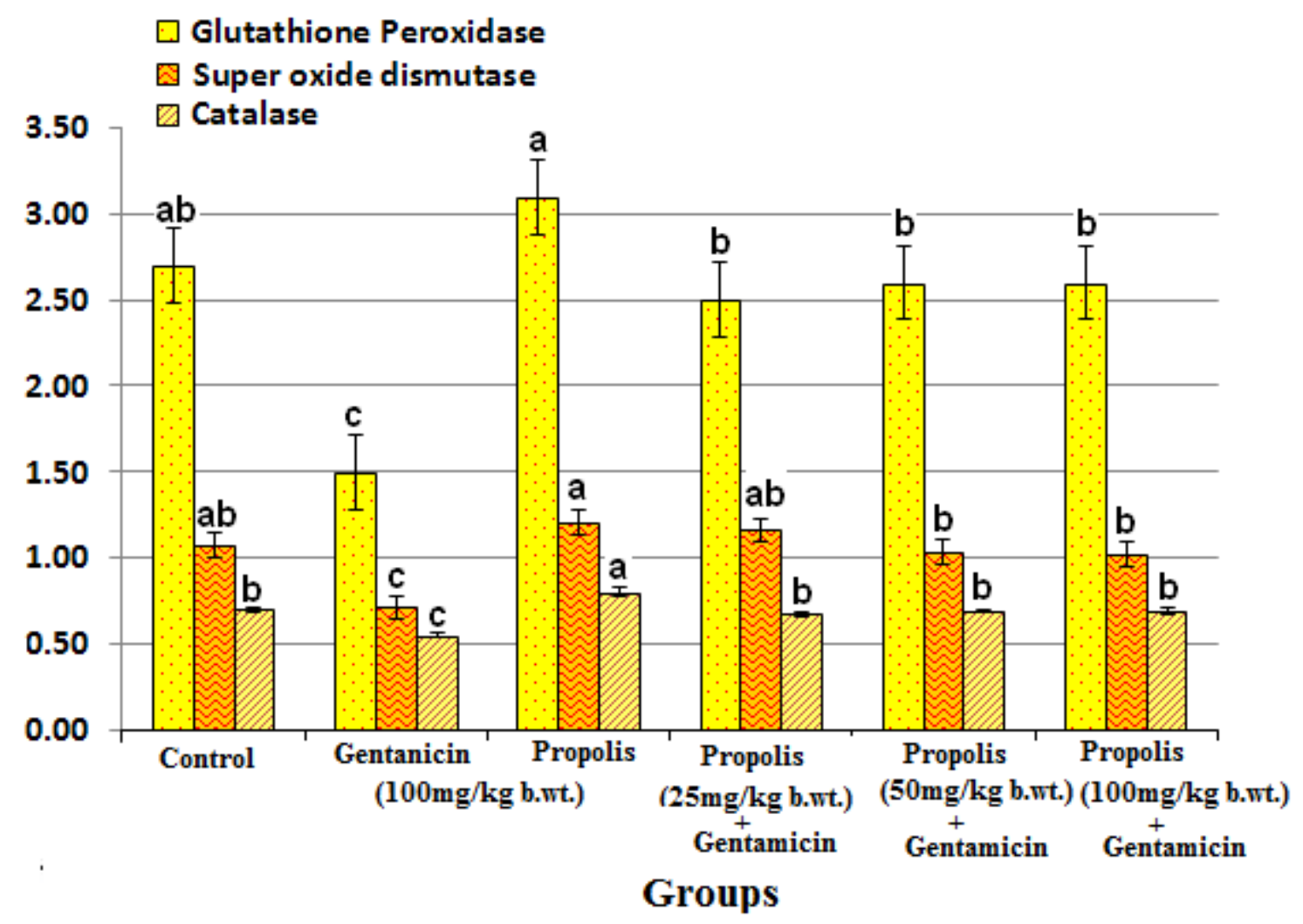

Fig. 1: Effect of gentamicin and propolis on expression pattern of antioxidants enzymes mRNA levels in renal tissue of different groups of rats; the ratio between the relative level of the target amplification product over the $\beta$-actin (internal control) was calculated as normalized gene expression. Different letters on different groups in the same enzyme are significantly different at $P<0.05$. (Mean $\pm S E$ ). Means for the same enzyme with different letters are significant at $P<0.05$.

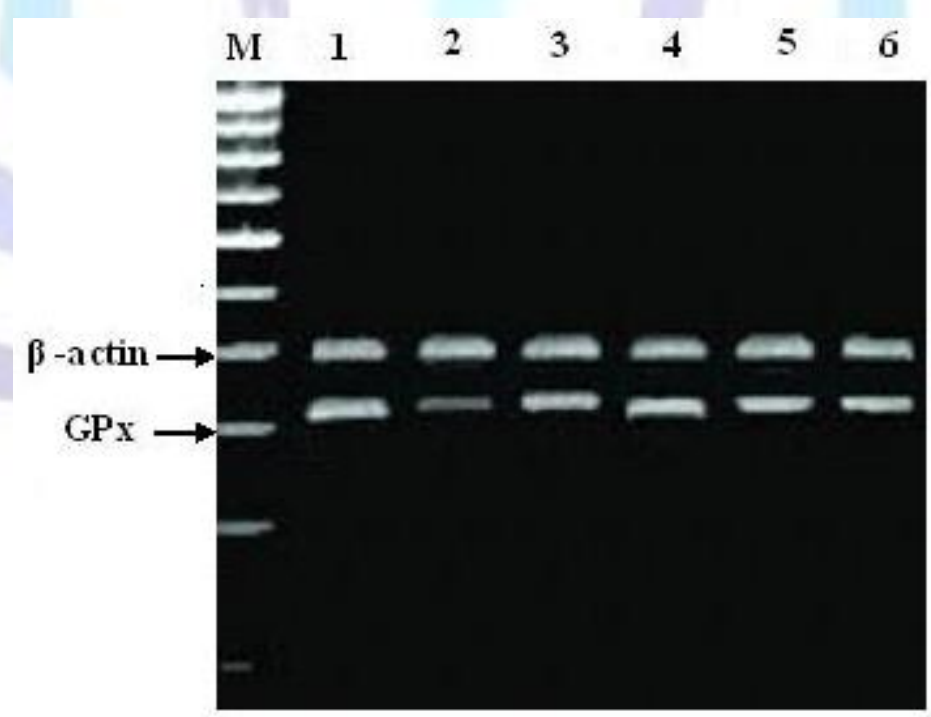

Fig. 2 Effect of gentamicin, and propolis on expression pattern of glutathione peroxidase (GPx) mRNA level in kidney of rats. The 354 and $374 \mathrm{bp}$ fragments represent GPx transcript, $\beta$-actin as internal standard respectively; lane M: molecular marker (100 bp); Lane 1: Control, lane 2: gentamicin, lane 3: propolis (100mg/kg b.wt.), lane 4: propolis (25mg/kg b.wt.)+gentamicin, lane 5: propolis (50mg/kg b.wt.) + gentamicin, lane 6: propolis (100 mg/kg b.wt.) + gentamicin. 


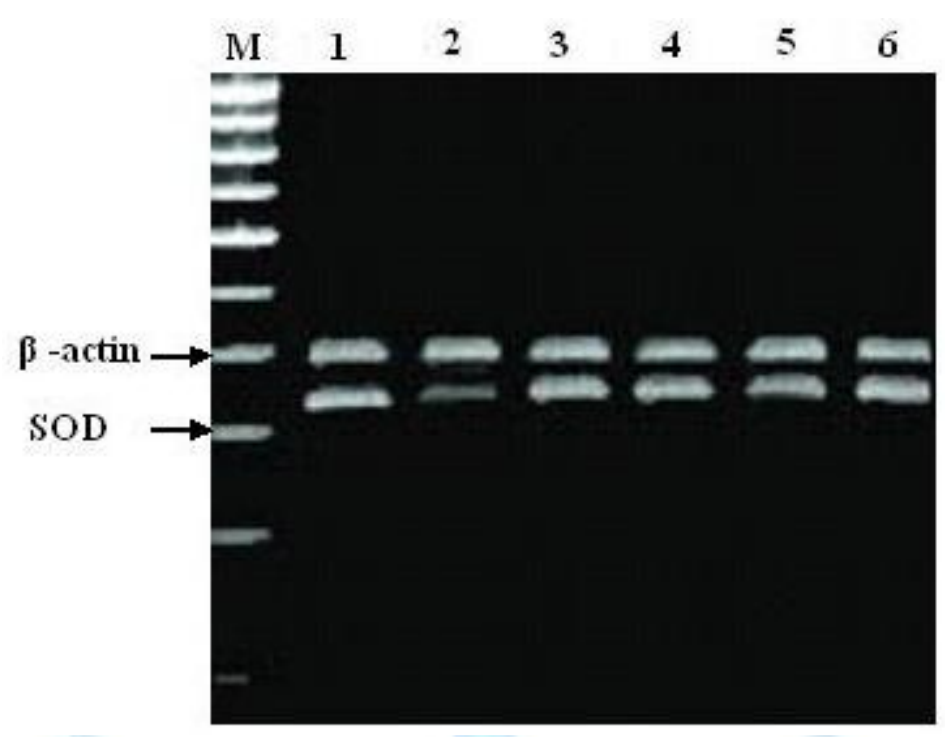

Fig. 3: Effect of gentamicin and propolis on expression pattern of SOD mRNA level in kidney of rats. The 370 and 374 bp fragments represent SOD transcript, $\beta$-actin as internal standard respectively; lane M: molecular marker (100 bp). Lane 1: control, lane 2: gentamicin, lane 3: propolis (100mg/kg b.wt.), lane 4: propolis (25mg/kg b.wt.)+gentamicin, lane 5: propolis (50mg/kg b.wt.) + gentamicin, lane 6: propolis (100 mg/kg b.wt.) + gentamicin.

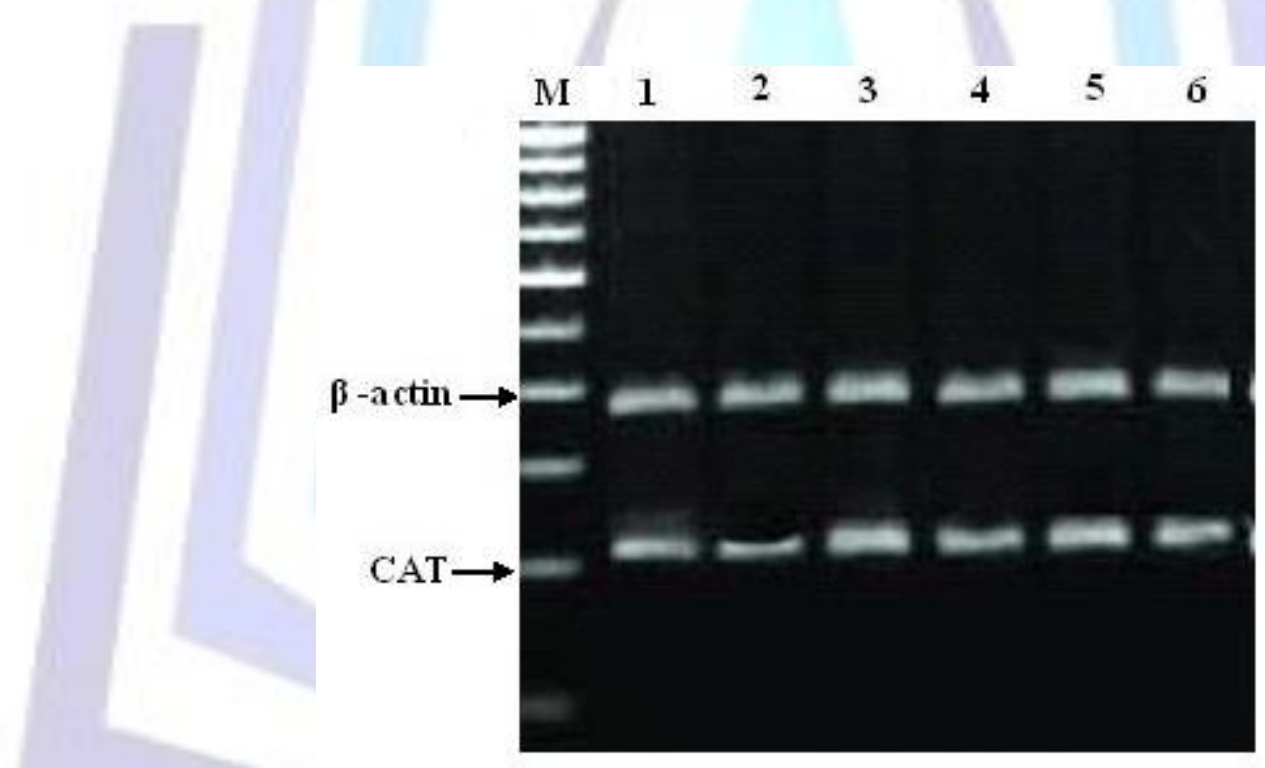

Fig. 4 Effect of gentamicin and propolis on expression pattern of CAT mRNA level in kidney of rats. The 229 and 374 bp fragments represent CAT transcript, $\beta$-ctin as internal standard respectively; lane M: molecular marker (100 bp). Lane 1: control, lane 2: gentamicin, lane 3: propolis (100 mg $/ \mathrm{kg}$ b.wt.), lane 4: propolis (25mg/kg b.wt.)+gentamicin, lane 5: propolis (50mg/kg b.wt.) + gentamicin, lane 6: propolis (100 mg/kg b.wt.) + gentamicin.

\subsection{DNA fragmentation}

The percentage of DNA fragmentation in kidney of rats treated with GM was much higher than that of control. Animals treated with propolis showed a decrease in the percentage of DNA fragmentation. On the other hand, animals treated with gentamicin and propolis at any of the three tested doses showed a significant improvement in the percentage of DNA fragmentation towards the control values (Table 4). 
Table 4 Effects of propolis on percentage of DNA fragmentation on renal tissue of rats treated with Gentamicin $(100 \mathrm{mg} / \mathrm{kg}$, i.p.).

\begin{tabular}{|l|c|c|}
\hline \multicolumn{1}{|c|}{ Parameters } & $\begin{array}{c}\text { DNA Fragmentation } \\
\text { Groups }\end{array}$ & $\begin{array}{c}\text { Change } \\
\text { (\%) }\end{array}$ \\
\hline Control(normal saline) & 6.5 & -- \\
\hline Gentamicin(100mg.kg/b.wt. i.p.) & 14 & +7.5 \\
\hline Propolis(100mg.kg/b.wt. orally) & 5.7 & -0.8 \\
\hline $\begin{array}{l}\text { Propolis(25mg.kg/b.wt. orally } \\
\text { +Gentamicin) }\end{array}$ & 7.3 & +0.8 \\
\hline $\begin{array}{l}\text { Propolis(50mg.kg/b.wt. orally } \\
\text { +Gentamicin) }\end{array}$ & 7 & +0.5 \\
\hline $\begin{array}{l}\text { Propolis(100mg.kg/b.wt. orally } \\
\text { +Gentamicin) }\end{array}$ & 7.2 & +0.7 \\
\hline
\end{tabular}

\section{DISCUSSION}

The present study was conducted to evaluate the protective effect of propolis against GM- induced renal dysfunction and antioxidant enzymes activity associated with nephrotoxicity and on gene expression of GPx, SOD, and CAT as well as DNA fragmentation in renal tissue.

Gentamicin caused a significant $(P<0.05)$ elevation of serum creatinine, serum urea levels and the activity of serum AST when compared to control group. Results of this study confirmed that GM at a dose of $100 \mathrm{mg} / \mathrm{kg} / \mathrm{day}$ for 7 days produces nephrotoxicity as evident by the reduction in glomerular filtration rate which is shown by increase in serum creatinine. This impairment in glomerular function was accompanied by an increase in blood urea nitrogen. Serum creatinine concentration is more significant than the serum urea level in the earlier phases of kidney disease. On the other hand, blood urea nitrogen begins to rise only after a marked renal parenchymal injury occurs [33].

GM caused oxidative stress and consequently decreased the activities of the antioxidant enzymes (GPx, SOD, and CAT). Because of GM has been shown to enhance the generation of ROS [34] which have been suggested as a causative agent of cell death in different pathological states including various models of renal diseases [35]. It has been shown that the altered concentrations of various biochemical indicators of oxidative stress in kidney tissue are due to GM [36]. GM-induced renal damage is probably due to rapid changes in membrane lipid composition which may be induced by free radical-initiated lipid peroxidation [37]. This view is supported by increased lipid peroxidation byproducts (LPX) levels; one of the aldehydic products of lipid peroxidation, in GM treated rats [38].

Oral administration of propolis exhibited a marked antioxidant effect since it alleviated the GM-induced oxidative stress. The antioxidant effect of propolis is probably due to its activity in scavenging of hydroxyl, superoxide free radicals, and lipid peroxides [39]. Propolis and its polyphenolic/flavonoid components have been previously reported to chelate metal ions and scavenge singlet oxygen, superoxide anions, proxy radicals, hydroxyl radicals and peroxy nitrite [40].

Nephrotoxicity is mediated by free radicals or by depletion of endogenous pool of antioxidants such as GSH. Oxidative stress was characterized by increased lipid peroxidation and/or altered non-enzymatic and enzymatic antioxidant systems. Cumulative evidence suggested that various enzymatic and non-enzymatic systems have been developed by mammalian cells to cope with ROS and other free radicals [41]. Several agents that scavenge or interfere with the production of ROS have been successfully used to ameliorate GM nephropathy [42]. This protective effect was associated with the ability of propolis to prevent the increase in lipid peroxidation and the fall in the antioxidant enzymes activity observed in renal cortex of rats with GM nephropathy. In addition, propolis treatment also partially prevented the decrease in serum GPx, which is synthesized almost exclusively in kidney proximal tubular cells [43, 44] and may be used as a marker of tubular damage [45]. Moreover, the elevation in glomerular antioxidant enzymes (GPx, SOD and CAT) protects renal function against the injury induced by ROS $[\mathbf{4 1}, \mathbf{4 6}]$. The exaggerated production of ROS in GM nephrotoxicity could induce inactivation of antioxidant enzymes. The decrease of ROS induced by propolis, which was made evident by the prevention in the lipid peroxidation rise, may be involved in the preservation of SOD and GPx activity in the GM+EEPgroup. The decrease in CAT protein content and mRNA levels also may be involved in the low CAT activity [47]. 
GM induced depletion of GSH was restored by propolis treatment, Thus, EEP may play a key role against GM intoxication by influencing the cellular GSH pool. In the present study, GM-induced renal injury was associated with increase lipid peroxidation byproducts (LPx). Similar results have been previously reported [48]. Propolis treatment significantly restored the LPx to values nearly similar to control one confirming its antioxidant effect and indicating its protective effect against GM induced peroxidative damage. Several active constituents and organic compounds present in propolis extract could act synergistically and inhibited LPx and acting as antioxidants diminishing GM induced peroxidative renal damage.

The activity of SOD is a sensitive index in hepatorenal damage as it scavenges the superoxide anion to form hydrogen peroxide leading to diminish the toxic effects. The CAT is an enzymatic antioxidant widely distributed in all animal tissues that decomposes hydrogen peroxide and protects the tissue from highly reactive hydroxyl radicals. Therefore, the reduction in the activity of these two enzymes may result in a number of deleterious effects due to the accumulation of superoxide radicals and hydrogen peroxide. Recent evidence suggests a role of ROS metabolites in gentamicin toxicity [49]. Gentamicin was found to enhance the generation of superoxide anions and hydroxyl radicals from renal cortical mitochondria. Such oxygen free radicals play an important role in pathogenesis of nephrotoxicity by gentamicin [50]. In the present study, propolis extract significantly restored the renal SOD and CAT activity indicating that propolis extract could scavenge reactive free radicals that eventually lessen the oxidative damage to the tissues and subsequently improve the activities of these antioxidant enzymes. Propolis has also similar protective effect against kainate-induced neurotoxicity via decreasing lipid peroxidation in hippocampus [50]. Moreover propolis may play a hepatoprotective role through reducing oxidative stress in living system [51, 52]. In addition, propolis was reported to increase serum GSH, CAT and pancreatic SOD activities in streptozotocin-induced diabetic rats, an effect which was attributed to its antioxidant potential $[52,53]$. Phytochemical investigations of propolis have demonstrated the presence of flavonoids and polyphenolic components as main active ingredients having potent antioxidant activities [54]. The antioxidative property of propolis extract may be due to its active chemical constituents.

In this study, GM caused significant increase in the percentage of DNA fragmentation in kidney, this is in agreement with others as they reported that gentamicin induce DNA fragmentation associated with apoptosis in the kidney of rats[55]. Similar observation was also reported in kidney cells of mice [56]. The present data revealed that GM significantly decreased the gene expressions of antioxidant enzymes (GPx, SOD and CAT). This effect may be due to a decrease in antioxidant gene transcription as reported by others [57]. The decreased gene expression may explain the protective effect of other antioxidants against gentamicin-induced nephrotoxicity $[\mathbf{5}, \mathbf{5 8}]$.

\section{CONCLUSION}

Propolis treatment prevented or ameliorated the renal alterations induced by GM administration as indicated by maintenance of the activity of antioxidant enzymes and gene expression changes associated with GM nephrotoxicity as well as improvement of renal functions. However, further experiments are required to isolate the active constituents of propolis and explore their efficacy.

\section{6-REFERENCES}

[1] Watanabe, A., Nagai, J., Adachi, Y., Katsube, T., Kitahara, Y., Murakami, T., and Takano, M. 2004. Targeted prevention of renal accumulation and toxicity of gentamicin by aminoglycoside binding receptor antagonists. J. Controlled Release 95: 423- 433.

[2] Ademuyiwa, O., Ngaha, E.O., and Ubah, F.O. 1990. Vitamin E and selenium in gentamicin nephrotoxicity. Hum. Exp. Toxicol. 9: 281-288.

[3] Sha, S.H., and Schacht, J. 1999. Formation of reactive oxygen species following bioactivation of gentamicin. Free Radical Biol. Med. 26: 341-347.

[4] Cuzzocrea, S., Mazzon, E., Dugo, L., Serraino, I., Paola, R.D., Britti, D. Sarro, A.D., Pierpaoli, S., Caputi, A.P., Masini, E., and Salvemini, D. 2002. A role for superoxide in gentamicin-mediated nephropathy in rats. Eur. J. Pharmacol. 450: 6776.

[5] Maldonado, P.D., Barrera, D., Madinacampos, O.N., Hernandez- Pando, R., Ibarra-Rubioand, M.E., and Pedraza-Chaverri, J. 2003. Aged garlic extract attenuates gentamicin-induced renal damage and oxidative stress in rats. Life Sci. 20: $2543-$ 2563.

[6] Hegazi, A.G., Abd El Hady, F.K., El Menway, F.A., and Al Mehdar, H. 2004. Egyptian propolis: 5 Influence of propolis adminestration on some chicken biochemical parameters. J. Appl. Vet. Sci. NRC 1: 43-58.

[7] Nassar, S.A., Mohamed, A.H., Soufy, H., Nasr, S.M., and Mahran, K.M. 2012. Immunostimulant effect of Egyptian propolis in rabbits. The ScientificWorld J., Volume 2012, Article ID 901516, 9 pages, doi:10.1100/2012/901516.

[8] Nassar, S.A., Mohamed, A.H., Soufy, H., and Nasr, S.M. 2013. Protective effect of Egyptian propolis against rabbit pasteurellosis. Biomed Res. Int. Volume 2013, Article ID 163724, 9 pages, http://dx.doi.org/10.1155/2013/163724

[9] Chen, C.N., Weng, M.S., Wu, C.L., and Lin, J.K. 2004. Comparison of radical scavenging activity, cytotoxic effects and apoptosis induction in human melanoma cells by Taiwanese propolis from different sources. Evid. Based Complement. Alternat. Med. 1: 175-185. 
[10] Perron, N.R., and Brumaghim, J.L. 2009. A review of the antioxidant mechanisms of polyphenol compounds related to iron binding. Cell Biochem. Biophys. 53: 75-100.

[11] Izuta, H., Narahara, Y., Shimazawa, M., Mishima, S., Kondo, S., and Hara, H. 2009. 1,1- Diphenyl-2-picrylhydrazyl radical scavenging activity of bee products and their constituents determined by ESR. Biol. Pharm. Bull. 32: 19471951

[12] Russo, A., Cardile, V., Sanchez, F., Troncoso, N., Vanella, A., and Garbarino, J.A. 2004. Chilean propolis: antioxidant activity and antiproliferative action in human tumor cell lines. Life Sci. 76: 545-558.

[13] Newairy, A.A., Salama, A.F., Hussien, H.M., and Yousef, M.I. 2009. Propolis alleviates aluminium-induced lipid peroxidation and biochemical parameters in male rats. Food and Chem. Toxicol. 47: 1093-1098.

[14] NRC (Nutritional research council) 1995. Nutrient Requirements of Laboratory Animals. Nutrient Requirements of the rat. Fourth Revised ed. National Academy Press, Washington, D.C., pp 11-79.

[15] Patton, C.J., and Crouch, S.R. 1977. Calorimetric determination of urea. Analyt. Chem. 49: 464-469.

[16] Houot, O. 1985. Interpretation of Clinical Laboratory Tests." ed. by Siest, G., Henny, J., Schiele, F., and Young, D.S. Biochemical publications pp. 220-234.

[17] Reitman, S.M.D., and Frankel, S. 1957. A colorimeter method for determination of serum glutamic oxaloacetic acid and glutamic pyruvic acid transferases. Am. J. Clin. Pathol. 28: 56-63

[18] Ellman, G.L.1959. Tissue sulfhydryl groups. Arch. Biochem. Biophys. 742: 214-226.

[19] Ohkawa, H., Ohishi, N., and Yagi, K. 1979. Assay for lipid peroxides in animal tissues by thiobarbituric acid reaction. Analyt. Biochem. 95:351-358.

[20] Paglia, D.E., and Valentine, W.N. 1967. Studies on the quantitative and qualitative characterization of erythrocyte glutathione peroxidase. J. Lab. Clin. Med. 70: 158-169.

[21] Nishikimi, M., Appaji, N., and Yagi, K., 1972. The occurrence of superoxide anion in the reaction of reduced phenazine methosulfate and molecular oxygen. Biochem. Biophys. Res. Commun. 46: 849-854.

[22] Aebi, H.E., 1984. Catalase in vitro. Methods Enzymol. 105: 121-126.

[23] Lowry, O.H., Rosenbrough, N.J., Lewis-Farr, A., and Randall, R.J., 1951. Protein measurement with folin-phenol reagent. J. Biol. Chem. 193: 265-275.

[24] Raben, N., Nichols R.C., Martiniuk F., and Plotz P.H.1996. Amodel of mRNA splicing in adult lysosomal storage disease (glycogenosis type II). Hum. Mol. Genet. 5: 995-1001

[25] Robert, C., McGraw, S., Massicotte, L., Pravetoni, M., Gandolfi, F., and Sirard, M.A.2002. Quantification of housekeeping transcript levels during the development of bovine preimplantation embryos. Biol. Reprod. 67: 1465-1472.

[26] Lyons, L.A., Laughlin, T.F., Copeland, N.G., Jenkins, N.A., Womack, J.E., and O’Brien, S.J. 1997. Comparative anchor tagged sequences (CATS) for integrative mapping of mammalian genomes. Nat. Genet. 15: 47-56.

[27] Spencer, W.E., and Christensen, M.J. 1999. Multiplex relative RT-PCR method for verification of differential gene expression, Biotechniques 27: 1044-1052.

[28] Shaffer, J.B., and Preston, K.E., 1990. Molecular analysis of an acatalasemic mouse mutant. Biochem. Biophys. Res. Commun. 173:1043-1050.

[29] Sambrook. L, Fritsch, E.F., and Maniatis. T. 1989. Molecular Cloning: A Laboratory Manual, Second ed. Cold Spring Harbor Laboratory Press, Cold Spring Harbour, NY.

[30] Xu, R., Zhao, W., Xu, J., Shao, B., and Qin, G. 1996. Studies on bioactive saponins from Chinese medicinal plants. Adv. Exp. Med. Biol. 404: 371-382.

[31] Kamalay, J., Raman, T., and Rufener, G.K. 1990. Isolation and analysis of genomic DNA from single seeds. Crop Sci. 30: 1079-1084

[32] Snedecor, G.W., and Cochran, W.G. 1989. Statistical Methods. Eighth ed. Ames, lowa State University Press, USA

[33] Erdem, A., Gundogan, N.U., Usubutun, A. Kilinc, K., Erdem, S.R., Kara, A., and Bozkurt, A., 2000. The protective effect of taurine against gentamicin-induced acute tubular necrosis in rats. Nephrol. Dial. Transplant. 15: 1175-1182.

[34] Yanagida, C., Ito, K., Komiya, I., and Horie, T. 2004. Protective effect of fosfomycin on gentamicin-induced lipid peroxidation of rat renal tissue. Chemico-Biological Interactions 148: 139-147.

[35] Baliga, R., Ueda, N., Walker, P.D.,and Shah, S.V. 1999. Oxidant mechanisms in toxic acute renal failure. Drug Metab. Rev. 31: 971-997.

[36] Yang, C.L. Du, X.H., and Han, Y.X.1995. Renal cortical mitochondria are the source of oxygen free radicals enhanced by gentamicin. Renal Failure 17:21-26. 
[37] Sandhya, P., and Varalakshmi, P. 1997. Effect of lipoic acid administration on gentamicin-induced lipid peroxidation in rats. J. Appl. Toxicol. 17: 405-408.

[38] Parlakpinar, H., Tasdemir, S., Polat, A., Bay-Karabulut A., Vardi, N., Ucar M., and Acet, A. 2005. Protective role of caffeic acid phenethyl ester (cape) on gentamicin-induced acute renal toxicity in rats. Toxicol. 207: 169-177.

[39] Jasprica, D., Mornar, A., Debelijak, Z., Smolcic-Bubalo, A., Medic- Saric, M., Mayer, L., Romic, Z., Bucan, K., Balog, T., Sobocanec, S., and Sverko, V. 2007. In vivo study of propolis supplementation effects on antioxidative status and red blood cells. J. Ethnopharmacol. 110: 548-554.

[40] Ferrali, M., Signorini, C., and Caciotti, B. 1997. Protection against oxidative damage of erythrocytes membrane by the flavinoid quercetin and its relation to iron chelating activity. FEBS Lett. 416: 123-129.

[41] Khan, R.A., and Khan, M.R. 2010. Sumaira Sahreen Evaluation of Launaea procumbens use in renal disorders: A rat model. J. Ethnopharmacol. 128: 452-461

[42] Ali, B.H., and Bashir, A.K. 1996. Effect of superoxide dismutase treatment on gentamicin nephrotoxicity in rats. Gen. Pharmacol. 27: 349-353.

[43] Avissar, N.S., Ornt, D.B., Yagil, Y., Horowitz, S., Watkins, R.H., Kerl, E.A., Takahashi, K., Palmer, I.S., and Cohen, H.J. 1994. Human kidney proximal tubule are the main source of plasma glutathione peroxidase. Am. J. Physiol. 266: C367C375.

[44] Nakane, T., Asayama, K., Kodera, K., Hayashibe, H., Uchida, N., and Nakazawa, S. 1998. Effect of selenium deficiency on cellular and extracellular glutathione peroxidases: immunochemical detection and mRNA analysis in rat kidney and serum. Free Radical Biol. Med. 25: 504-511.

[45] Whitin, J.C., Tham, D.M., Bhamre, S., Ornt, D.B., Scandling, J.D., Tune, B.M., Salvatierra, O., Avissar, N., and Cohen, H.J. 1998. Plasma glutathione peroxidase and its relationship to renal proximal tubule function. Mol. Genet. Metab. 65: 238245.

[46] Yoshioka, T., Bills, T., Moore-Jarrett, T., Greene, H.L., Burr, I.M., and Ichikawa, I. 1990. Role of intrinsic antioxidant enzymes in renal oxidant injury. Kidney Int. 38: 282-288.

[47] Pedraza-Chaverrí, J., Granados-Silvestre, M.D., Medina-Campos, O.N., Maldonado, P.D., Olivares-Corichi, I.M., and Ibarra-Rubio, M.E. 2001. Post-transcriptional control of catalase expression in garlic-treated rats.Molecular and cellular Cell. Biochem. 216: 9-19.

[48] Sener, G., Sehirli, O., Cetinel, S., Yegen, B.G., Gedik, N., and Ayanoglu-Dulger, G., 2005. Protective effects of MESNA (2mercaptoethane sulfonate) against acetaminophen-induced hepatorenal oxidative damage in mice. J. Appl. Toxicol. 25: 20-29.

[49] Fouad, A.A., and Mahgoub, S.S., 2004. Protective effect of losartan, garlic and melatonin against gentamicin-induced nephrotoxicity in albino rats. Alexandria J. Pharmac. Sci. 2:97-101.

[50] Kwon, Y.S., Park, D.H., Shin, E.J., Kwon, M.S., Ko, K.H., Kim, W.K., Jhoo, J.H., Jhoo, W.K., Wie, M.B., Jung, B.D., and Kim, H.C. 2004. Antioxidant propolis attenuates kainite induced neurotoxicity via adenosine A1-receptor modulation in the rat. Neurosci. 355: 231-235.

[51] Bhadauria, M., Nirala, S.K., and Shukla, S. 2007. Propolis protects CYP2E1enzymatic activity and oxidative stress induced by carbon tetrachloride. Mol. Cell Biochem. 302: 215-224.

[52] Orsolic, N., Sirovina, D., Končić, M.Z., Lacković, G., and Gregorović, G. 2012. Effect of Croatian propolis on diabetic nephropathy and liver toxicity in mice. BMC Complement. Altern. Med., 2012, 12:117. doi: 10.1186/1472-6882-12-117.

[53] EL-Sayed, M.S, Abo-Salem, O.M., ALEM, A., Aly, H.A., and Mansour, A.M. 2009. Potential antidiabetic and hypolipidemic effects of propolis extract in streptozotocin-induced diabetic rats. Pak. J. Pharm. Sci. 22: 168-174.

[54] Hosnuter, M., Gurl, A., Babuccu, O., Armutcu, F., Kargi, E., and Isikdemir, A. 2004. The effect of CAPE on lipid peroxidation and nitric acid levels in the plasma of rats of rats following thermal injury. Burns 30: 121-125.

[55] Martínez-Salgado, C., Eleno, N., Morales, A.I., Pérez-Barriocanal, F., Arévalo, M., and López-Novoa, J.M. 2004. Gentamicin treatment induces simultaneous mesangial proliferation and apoptosis in rats. Kidney Int. 65: 2161-2171.

[56] El-Ashmawy, I.M, El-Nahas, A.F., and Salama, O.M. 2006. Grape seed extract prevents gentamicin-induced nephrotoxicity and genotoxicity in bone marrow cells of mice. Pharmacol. Toxicol. 99: 230-236.

[57] Pedraza-Chaverrí, J., Maldonado, P.D., Medina-Campos, O., Olivares-Corichi I.M., Granados-Silvestre, M. A., Herna'ndezPando, R., and Ibarra-Rubio, M.E. 2000. Garlic ameliorates gentamicin nephrotoxicity: relation to antioxidant enzymes. Free Radical Biol. Med. 29: 602-611.

[58] Ali, B.A. 2002. The effect of treatment with the medicinal plant Rhazya stricta decne on gentamicin-induced nephrotoxicity in rats. Phytomed. 9: 385-389. 